\title{
The International Academy of Cytology Yokohama System for Reporting Breast Fine Needle Aspiration Biopsy Cytopathology
}

\author{
Andrew S. Field ${ }^{\mathrm{a}}$ Wendy A. Raymond ${ }^{\mathrm{b}}$ Fernando C. Schmitt ${ }^{\mathrm{c}}$ \\ a University of NSW and University of Notre Dame Medical Schools, and Department of Anatomical Pathology, \\ St Vincent's Hospital, Sydney, NSW, Australia; 'b South Australian Pathology, Department of Surgical Pathology, \\ Flinders Medical Centre, Flinders University of South Australia, and Clinpath, Adelaide, SA, Australia; ' Institute of \\ Molecular Pathology and Immunology of Porto University (IPATIMUP), Instituto de Investigação e Inovação em \\ Saúde and Medical Faculty, University of Porto, Porto, Portugal
}

Fine needle aspiration biopsy (FNAB) of the breast is globally one of the most commonly performed fine needle biopsies with a long history of successful application, initially in palpable lesions and then in impalpable lesions using ultrasound guidance [1]. In recent times, in many centers and programs in well-resourced countries, FNAB has been largely replaced by core needle biopsy (CNB) because of the perceived benefits of $\mathrm{CNB}$ as being able to provide a more definitive answer in proliferative lesions and in diagnosing malignancy, and with a lower insufficient or inadequate rate. To support this perception, publications dating back to the 1990s and early this century are often quoted, from an era before the advent of the routine use of ultrasound-guided FNAB and the use of rapid on-site evaluation [2]. This research is often based on varying cohorts of patients, varying procedural approaches and varying expertise of those performing the FNAB, which is often not stated $[2,3]$.

The overarching goals of the development of the International Academy of Cytology (IAC) System are to stimulate the appropriate use of breast FNAB, improve the reporting of breast FNAB, facilitate the communication between the cytopathologist and the clinical management

\section{KARGER}

(c) 2019 S. Karger AG, Basel

E-Mail karger@karger.com

www.karger.com/acy team, and to promote further research into breast disease utilizing FNAB to further benefit patient care. To do this, the IAC System has established a clear categorization of breast reports into five tiers, each with a clear definition and description, and a specified risk of malignancy (ROM) [1]. The ROM is then linked with management recommendations. These recommendations include several options because it is recognized that the management options available in well-resourced countries are often different to those in low- and middle-income countries, most particularly in the availability of imaging and CNB [1]. The System also crucially emphasizes that breast FNAB relies on the expertise of those performing the biopsy, making the direct smears and interpreting the material on the slides, and this requires good initial and ongoing training and clear communication with the clinicians managing patients with breast lesions.

The process of creating the reporting system was initiated by a core group of cytopathologists with considerable expertise and interest in reporting breast fine needle aspiration cytology, meeting under the auspices of the IAC in May 2016 at the International Congress of Cytology in Yokohama. Discussions led to the publication of a 
proposal in 2017 in Acta Cytologica and expansion of the writing team. Authors were asked to work in specific areas and to focus on a review of the literature and to provide draft summaries. The drafts were edited, collated and circulated to the authors' group. A questionnaire was placed on the University of Wisconsin website for general comments and the responses were integrated into the final documents, which will be published in full in a textbook. This method is recommended to others involved in developing reporting systems for FNAB cytology at other sites.

This special edition of Acta Cytologica begins with a lead overview article by Field AS and colleagues [1] that provides a rationale and summary of the new system. This is followed by two articles by Montezuma D, Malheiros D, and Schmitt FC [4] and Wong S, Rickard M, Earls P et al. [5] that detail studies based on current best practice in breast FNAB with analysis of performance measures. These performance measures are mentioned in the overview article and are used in the management table, because they reflect the current use of breast FNAB. The article by Brachtel EF and Hoda RS [6] provides a system- atic review of a range of previous studies detailing performance measures in breast FNAB, encompassing a longer period, and the data from this review has been incorporated into the general data in the text of the overview article.

This special edition then includes a review article of ancillary testing in breast FNAB by Beca F and Schmitt FC [7], an article on the management of axillary lymph nodes utilizing FNAB by Gibbons CE, Quinn CM, and Gibbons D [8], and an article on the diagnostic value of FNAB in male breast lesions by Hoda RS, Brachtel E et al. [9]. A review article of spindle cell lesions of the breast and their FNAB diagnosis by Michelow P and Field AS [10] follows, and the final article by Osamura RY, Matsui $\mathrm{N}$, and Okubo $\mathrm{M}$ et al. [11] reviews neuroendocrine lesions of the breast.

The authors hope that the new IAC System for reporting breast FNAB will invoke a fresh appraisal of the utility of this rapid, accurate and low-cost diagnostic test for all breast lesions, and that the accompanying articles will assist in a broader understanding and application of breast FNAB.

\section{References}

1 Wong S, Rickard M, Earls P, Arnold L, Bako B, Field AS. The International Academy of Cytology Yokohama System for reporting breast fine needle aspiration biopsy cytology: a single institutional retrospective study of the application of the system categories and the impact of rapid onsite evaluation. Acta Cytol. 2019 May 20:1-12. DOI: 10.1159/000500191.

2 Wang M, He X, Chang Y, Sun G, Thabane L. A sensitivity and specificity comparison of fine needle aspiration cytology and core needle biopsy in evaluation of suspicious breast lesions: A systematic review and meta-analysis. Breast. 2017 Feb;31:157-66.

3 Lieske B, Ravichandran D, Wright D. Role of fine-needle aspiration cytology and core biopsy in the preoperative diagnosis of screendetected breast carcinoma. Br J Cancer. 2006 Jul;95(1):62-6.
4 Montezuma D, Malheiros D, Schmitt F. Breast FNAB cytology using the newly proposed IAC Yokohama System for Reporting Breast Cytopathology: the experience of a single institution. Acta Cytol. 2019 Feb 15:1-6. DOI: 10.1159/000492638.

5 Wong S, Rickard M, Earls P, Arnold L, Bako B, Field AS. The IAC Yokohama System for reporting breast FNAB cytology: a single institutional retrospective study of the application of the system and the impact of ROSE. Acta Cytol. 2019 May 20:1-12. DOI: 10.1159/000500191.

6 Brachtel E, Hoda R. IAC Yokohama System for reporting breast FNAB cytology: a review of predictive values and risks of malignancy. Acta Cytol. 2019. DOI: 10.1159/000500704.

7 Beca F, Schmitt FS. Ancillary tests in breast FNAB cytology: a practical guide to current use.ActaCytol.2019.DOI:10.1159/000499697.
8 Gibbons CE, Quinn CM, Gibbons D. Fine needle aspiration biopsy management of the axilla in primary breast carcinoma. Acta Cytol.2019Mar20:1-5.DOI:10.1159/000496159.

9 Hoda RS, Arpin Iii RN, Gottumukkala RV, Hughes KS, Ly A, Brachtel EF. Diagnostic value of fine-needle aspiration in male breast lesions. Acta Cytol. 2019 Mar 22:1-9. DOI: 10.1159/000494486.

10 Michelow P, Field AS. Spindle cell lesions of the breast on fine needle aspiration biopsy: a review. Acta Cytol. 2019. DOI: 10.1159/000500703.

11 Osamura RY, Matsui N, Okubo M, Chen L, Field AS. Histopathology and cytopathology of neuroendocrine tumors and carcinomas of the breast: a review. Acta Cytol. 2019. DOI: $10.1159 / 000500705$. 